\title{
Intestinal absorption of carnosine and its constituent amino acids in $\operatorname{man}^{1}$
}

\author{
A. M. ASATOOR, J. K. BANDOH ${ }^{2}$, A. F. LANT, M. D. MILNE, AND \\ F. NAVAB \\ From the Medical Unit of the Westminster Hospital, London
}

SUMMARY Serum concentrations of $\beta$-alanine and L-histidine are compared in five normal adults after ingestion of the dipeptide carnosine ( $\beta$-alanyl-L-histidine) and after equivalent amounts of the constituent free amino acids. The results indicate that absorption is significantly more rapid after the ingestion of the amino acids than after the dipeptide. The use of the test in a case of Hartnup disease suggests that carnosine is taken up by intestinal cells as the dipeptide, but subsequent hydrolysis and delivery of the constituent amino acids to the portal blood is a slower process than transport of the free amino acids themselves.

Current views of intestinal amino acid absorption suggest that at least two mechanisms are involved. Free amino acids are actively transported against a concentration gradient from the intestinal lumen to the portal capillaries (Wiseman, 1951) and small peptides are taken up intact from the intestinal lumen, but are hydrolysed by the peptidases of the intestinal mucosal cells and appear in the portal blood or in serosal fluid as the corresponding free amino acids (Wiggans and Johnston, 1959; Newey and Smyth, 1960 and 1962). Evidence supporting intestinal uptake of intact peptides in man has been reported for the di- and tripeptides of glycine (Craft, Geddes, Hyde, Wise, and Matthews, 1968), plasma glycine levels being considerably higher 30 minutes after the ingestion of each peptide than after a corresponding amount of free glycine. This indicated a more rapid cellular uptake of peptide molecules than of the larger number of molecules of free glycine. Because of the marked differences in specific aminopeptidase activities within the microvillous membrane of the intestinal epithelium (Rhodes, Eicholz and Crane, 1967), conclusions drawn from studies with glycyl-glycine may not be generally applicable to the cellular mechanism of absorption of other peptides. Quite apart

\footnotetext{
${ }^{1}$ Address for reprints: Medical Unit, Westminster Hospital, Page Street Wing, London, SW1.

'Present address: Military Hospital, Accra, Ghana.
}

from the question of species differences in absorptive behaviour, the problem of oligopeptide absorption is complicated by the fact that about 400 different dipeptides can be formed from the amino acids of proteins, and the figure becomes much higher if tri- or higher peptides are considered.

Investigation of peptide absorption by tolerance tests in man involves difficulties in the supply of oligopeptides of sufficient purity, as these compounds are in most cases difficult to prepare in bulk. The dipeptide carnosine ( $\beta$-alanyl-Lhistidine) is readily available, and is necessarily ingested in considerable amounts by all nonvegetarians, as mammalian muscle contains up to $0.6 \%$ of carnosine (Davey, 1957). This paper compares serum levels of the constituent amino acids, $\beta$-alanine and $\mathrm{L}$-histidine, after ingestion of the peptide and corresponding quantities of the two free amino acids.

\section{Methods}

Five normal adults were investigated, each individual ingesting carnosine and equivalent amounts of a mixture of $\beta$-alanine and Lhistidine after an overnight fast. The two tolerance tests in each subject were carried out at 
intervals of at least two weeks. Dosage of carnosine was $0.286 \mathrm{~m} \mathrm{~mole} / \mathrm{kg}$ body weight, corresponding to $20 \mathrm{~m}$ mole per standard $70 \mathrm{~kg}$ male. Histidine and $\beta$-alanine were taken together in an amount which would be produced after hydrolysis of the above dose of carnosine. Both the dipeptide and the amino acid mixture were taken dissolved in $500 \mathrm{ml}$ water. Blood samples were obtained at zero time, and at 15, 30, and 45 minutes after ingestion of the solution. Serum for analysis was obtained with the minimum of delay. In one subject additional samples were analysed at 60 and 90 minutes after the mixture.

MATERIALS AND CHEMICAL METHODS Amino acids were analysed on the Technicon amino acid analyser using the standard procedure described in the Technicon Handbook (1966).

Carnosine, $\beta$-alanine, and $\mathrm{L}$-histidine were obtained from commercial sources and were found to be chromatographically pure.

\section{Results}

Peripheral paraesthesiae occurred in all subjects from about 15 to 45 minutes after ingestion of carnosine and of the mixture of the two amino acids, but otherwise no abnormal symptoms occurred. Since similar effects have not been described after ingestion of larger quantities of histidine alone, the paraesthesiae were presumably due either to $\beta$-alanine or to one of its metabolites. No $\beta$-alanine was detected in the basal serum specimens, but histidine concentration averaged $11.2 \mu$ moles $/ 100 \mathrm{ml}$ (range 8.6-17.0). All values for histidine in subsequent serum specimens are recorded as increments above the basal concentration. Carnosine was not detected in any serum sample.

Tolerance curves in the subject in whom additional serum samples were analysed are given in Figures 1 and 2. Peak concentrations of $\beta$-alanine occurred in the sample taken after 30 minutes, and of histidine in the 45-minute specimen. In the period of 15 to 30 minutes after the drink the maximum rate of increase in serum amino acid concentration was 1.25 times as rapid for $\beta$-alanine as for histidine in both tolerance tests. Similarly, the subsequent rate of decline after the peak concentrations was greater in the case of $\beta$-alanine. Comparing the two tolerance curves, the rate of rise of both serum $\beta$-alanine and of histidine in the 15 to 30 -minute period was 1.45 times as great after the free amino acids than after carnosine.

The individual results of the tolerance tests are given in Table $I$, and the means of concentrations from the five subjects in Figures 3 and 4.

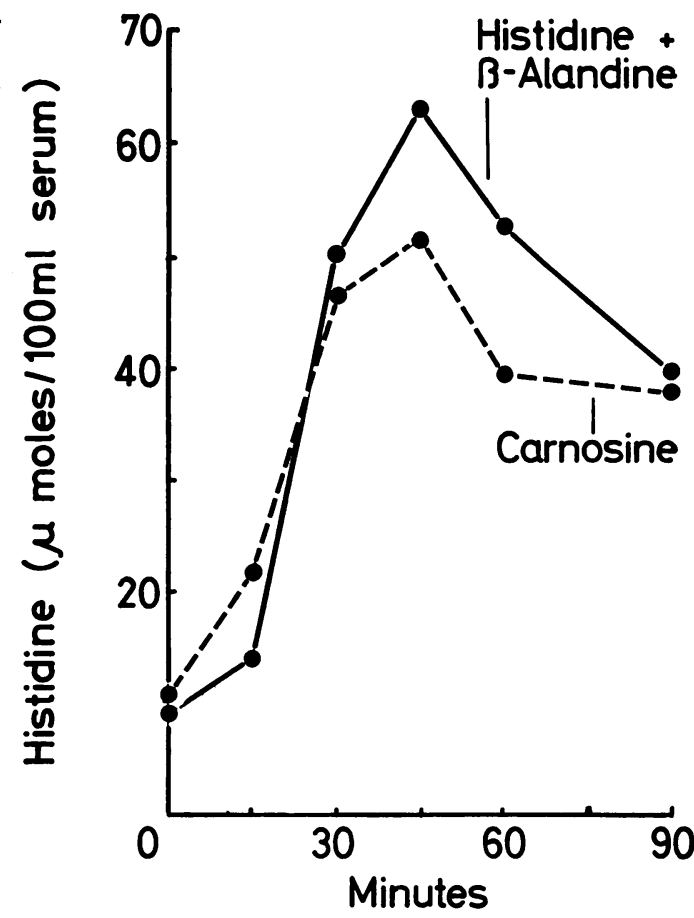

Fig. 1 Concentrations of serum histidine after ingestion of carnosine and the constituent free amino acids in a normal subject.

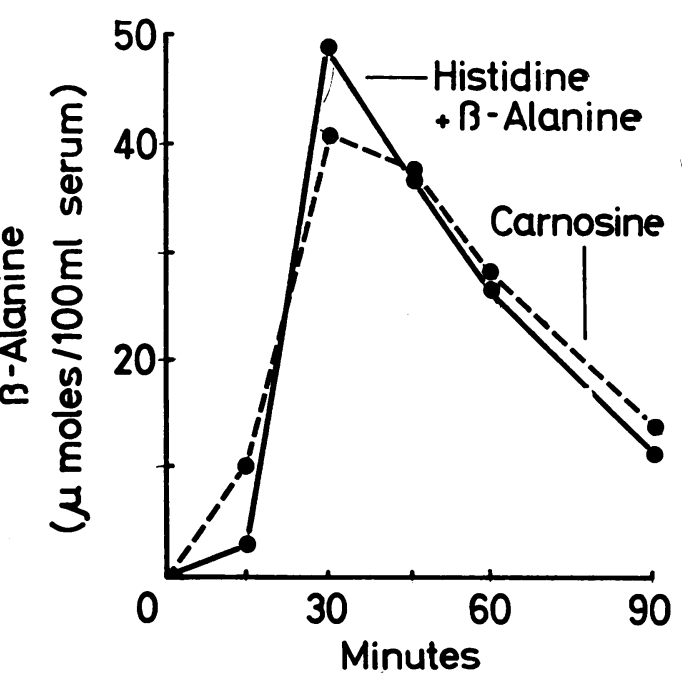

Fig. 2 Concentrations of serum $\beta$-alanine after ingestion of carnosine and the constituent free amino acids in a normal subject. 
and of $\beta$-alanine in the same subject at 30 and 45 minutes after the drink were greater after ingestion of the free amino acids than after carnosine. In the remaining analysis the result was identical. This could have occurred by chance alone at a probability value of one in $\mathbf{4 0 0}$ times. As the same individuals were used in both tolerance tests, the method of the paired $t$ test (Snedecor, 1946) is statistically valid. Using this technique the increments of serum amino acids are significantly higher after ingestion of the free amino acids in the 30- and 45-minute samples for histidine and in the 30-minute sample for $\beta$-alanine (Table I). In the 45-minute samples for $\beta$-alanine, the results are lower after carnosine ingestion, but the difference is not significant $(0.1>\mathrm{P}>0.05)$. The peak increment of $\beta$ alanine occurred at 30 minutes in three of the five subjects, and therefore the 45-minute sample in this case is not a satisfactory representation of the absorption rate of the amino acid. It can be concluded that absorption of both $\beta$-alanine and of histidine is significantly more rapid after ingestion of the free amino acids than after ingestion of the equivalent amount of carnosine.

\begin{tabular}{|c|c|c|c|c|c|c|}
\hline & Subject & $\begin{array}{l}\text { Free Amino } \\
\text { Acids }\left(X_{1}\right)\end{array}$ & $\begin{array}{l}\text { Carnosine } \\
\left(X_{\mathbf{2}}\right)\end{array}$ & $\left(X_{1}-X_{2}\right)$ & $\begin{array}{l}\text { Deviation } \\
\left(X_{1}-X_{2}-\hat{\mathbf{x}}\right)\end{array}$ & $\begin{array}{l}\text { Squared } \\
\text { Deviations }\end{array}$ \\
\hline \multirow[t]{2}{*}{$\begin{array}{l}\text { Histidine at } \\
30 \text { minutes }\end{array}$} & $\begin{array}{l}1 \\
2 \\
3 \\
4 \\
5\end{array}$ & $\begin{array}{r}41 \cdot 0 \\
36 \cdot 2 \\
51 \cdot 2 \\
17 \cdot 2 \\
4 \cdot 2\end{array}$ & $\begin{array}{r}36 \cdot 4 \\
24 \cdot 2 \\
41 \cdot 1 \\
5 \cdot 0 \\
1 \cdot 7\end{array}$ & $\begin{array}{r}4 \cdot 6 \\
12 \cdot 0 \\
10 \cdot 1 \\
12 \cdot 2 \\
2 \cdot 5\end{array}$ & $\begin{array}{r}-3.7 \\
3.7 \\
1.8 \\
3.5 \\
-5.8\end{array}$ & $\begin{array}{r}13.69 \\
13.69 \\
3.24 \\
12.25 \\
33.64\end{array}$ \\
\hline & $\begin{array}{l}\text { Total } \\
\text { Mean }\end{array}$ & $\begin{array}{c}149 \cdot 8 \\
30 \cdot 0 \\
t=4 \cdot 30\end{array}$ & $\begin{array}{r}108 \cdot 4 \\
21 \cdot 7\end{array}$ & $\begin{array}{c}41 \cdot 4 \\
\bar{X}=8 \cdot 3 \\
P<0.02\end{array}$ & & $S^{2}=19 \cdot 13$ \\
\hline \multirow[t]{2}{*}{$\begin{array}{l}\text { Histidine at } \\
45 \text { minutes }\end{array}$} & $\begin{array}{l}1 \\
2 \\
3 \\
4 \\
5\end{array}$ & $\begin{array}{l}54 \cdot 0 \\
41 \cdot 0 \\
48 \cdot 8 \\
35 \cdot 4 \\
26 \cdot 8\end{array}$ & $\begin{array}{l}41 \cdot 2 \\
36 \cdot 0 \\
48 \cdot 7 \\
14 \cdot 4 \\
16 \cdot 1\end{array}$ & $\begin{array}{r}12 \cdot 8 \\
5.0 \\
0 \cdot 1 \\
21 \cdot 0 \\
10 \cdot 7\end{array}$ & $\begin{array}{r}2.9 \\
-4.9 \\
-9.8 \\
11.1 \\
1.8\end{array}$ & $\begin{array}{r}8.41 \\
24.01 \\
96.04 \\
123.21 \\
3.24\end{array}$ \\
\hline & $\begin{array}{l}\text { Total } \\
\text { Mean }\end{array}$ & $\begin{array}{c}206 \cdot 0 \\
41 \cdot 2 \\
t=2 \cdot 77\end{array}$ & $\begin{array}{r}156 \cdot 4 \\
31 \cdot 3\end{array}$ & $\begin{array}{c}\quad 49.6 \\
\bar{x}=9.9 \\
P<0.05\end{array}$ & & $\begin{array}{r}254.91 \\
S^{2}=63.73\end{array}$ \\
\hline \multirow[t]{2}{*}{$\begin{array}{l}\beta \text {-alanine at } \\
30 \text { minutes }\end{array}$} & $\begin{array}{l}1 \\
2 \\
3 \\
4 \\
5\end{array}$ & $\begin{array}{r}48 \cdot 4 \\
37 \cdot 4 \\
55 \cdot 4 \\
15 \cdot 0 \\
1.5\end{array}$ & $\begin{array}{r}41 \cdot 0 \\
22 \cdot 7 \\
33 \cdot 6 \\
5.6 \\
1.2\end{array}$ & $\begin{array}{r}7 \cdot 4 \\
14 \cdot 3 \\
19 \cdot 8 \\
9 \cdot 4 \\
0 \cdot 3\end{array}$ & $\begin{array}{r}-2 \cdot 8 \\
4 \cdot 1 \\
9 \cdot 6 \\
-0.8 \\
-9.9\end{array}$ & $\begin{array}{r}7 \cdot 84 \\
16.81 \\
92 \cdot 16 \\
0.64 \\
98.01\end{array}$ \\
\hline & $\begin{array}{l}\text { Total } \\
\text { Mean }\end{array}$ & $\begin{array}{c}157.7 \\
35.5 \\
t=3.11\end{array}$ & $\begin{array}{r}104 \cdot 1 \\
20 \cdot 8\end{array}$ & $\begin{array}{c}51 \cdot 2 \\
\overline{\mathrm{X}}=10 \cdot 2 \\
\mathrm{P}<0.05\end{array}$ & & $S^{2}=53.87$ \\
\hline \multirow[t]{2}{*}{$\begin{array}{l}\beta \text {-alanine at } \\
45 \text { minutes }\end{array}$} & $\begin{array}{l}1 \\
2 \\
3 \\
4 \\
5\end{array}$ & $\begin{array}{l}36 \cdot 6 \\
30 \cdot 0 \\
48 \cdot 4 \\
39 \cdot 0 \\
27 \cdot 8\end{array}$ & $\begin{array}{r}36 \cdot 6 \\
22 \cdot 4 \\
40 \cdot 4 \\
12 \cdot 0 \\
9 \cdot 3\end{array}$ & $\begin{array}{c}0 \\
7 \cdot 6 \\
8 \cdot 0 \\
27 \cdot 0 \\
18 \cdot 5\end{array}$ & $\begin{array}{r}-12.2 \\
-4.6 \\
-4.2 \\
14.8 \\
6.3\end{array}$ & $\begin{array}{r}148.84 \\
21 \cdot 16 \\
17.64 \\
219.04 \\
39.69\end{array}$ \\
\hline & $\begin{array}{l}\text { Total } \\
\text { Mean }\end{array}$ & $\begin{array}{c}181 \cdot 8 \\
36 \cdot 4 \\
t=2 \cdot 58\end{array}$ & $\begin{array}{l}120 \cdot 7 \\
24 \cdot 1 \\
\\
0 \cdot 1\end{array}$ & $\begin{array}{c}\quad 61 \cdot 1 \\
\bar{x}=12.2 \\
P<0.05\end{array}$ & & $S^{2}=\begin{array}{r}446.37 \\
111.59\end{array}$ \\
\hline
\end{tabular}

Table I Increments in serum histidine and $\beta$ alanine after ingestion of carnosine and free constituent amino acids ( $\mu$ mole $/ 100 \mathrm{ml}$ )

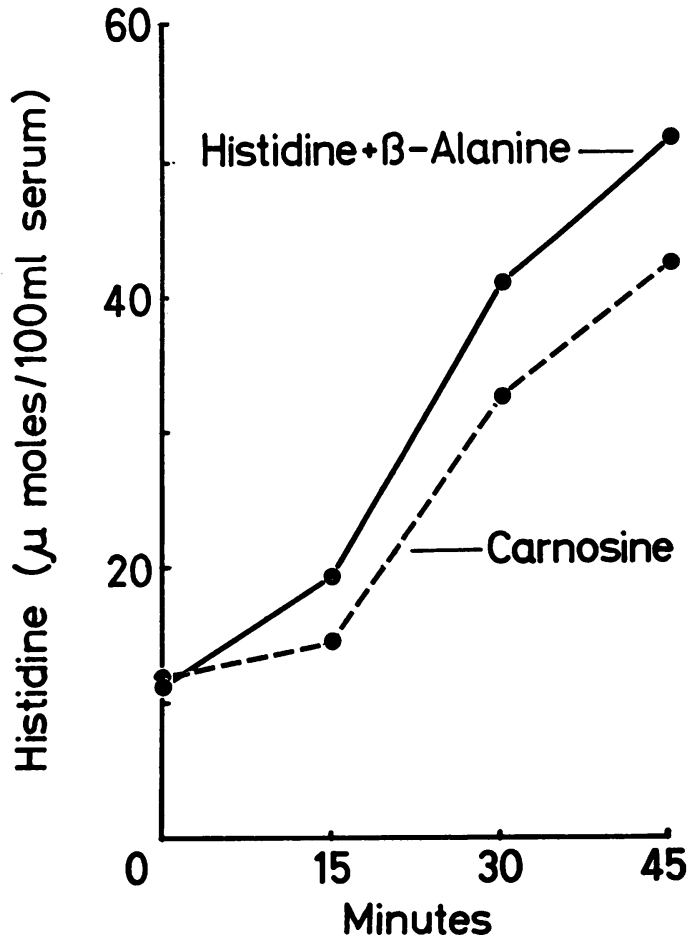

Fig. 3 Mean serum concentrations of histidine during a 45-minute period after ingestion of carnosine and the constituent free amino acids in five normal subjects.

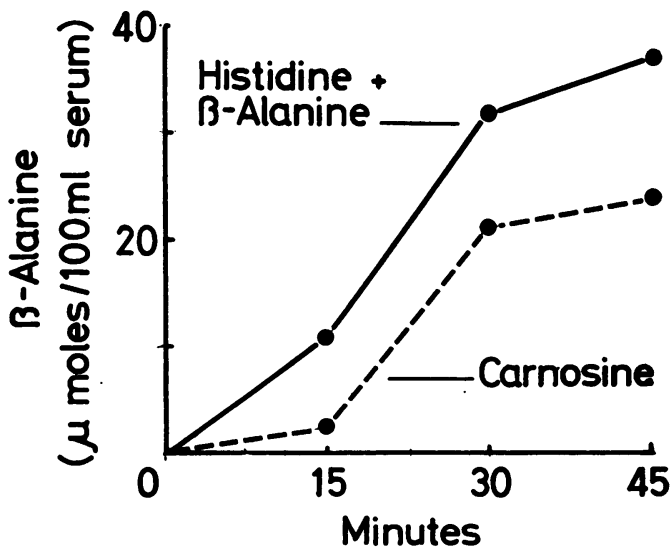

Fig. 4 Mean serum concentrations of $\beta$-alanine during a 45-minute period after ingestion of carnosine and the constituent free amino acids in five normal subjects. 


\begin{tabular}{llllll}
\hline & \multicolumn{2}{l}{$\begin{array}{l}\text { Serum Histidine } \\
(\mu \text { moles } / 100 \mathrm{ml} / \mathrm{min})\end{array}$} & & \multicolumn{2}{l}{$\begin{array}{l}\text { Serum } \beta \text {-analine } \\
(\mu \text { moles } / 100 \mathrm{ml} / \mathrm{min})\end{array}$} \\
\cline { 2 - 3 } Subject & $\begin{array}{l}\text { After Free } \\
\text { Amino Acids }\end{array}$ & $\begin{array}{l}\text { After } \\
\text { Carnosine }\end{array}$ & & $\begin{array}{l}\text { After Free } \\
\text { Amino Acids }\end{array}$ & $\begin{array}{l}\text { After } \\
\text { Carnosine }\end{array}$ \\
\hline 1 & 2.43 & 1.65 & & 3.01 & 2.06 \\
2 & 1.18 & 1.52 & & 1.02 & 1.43 \\
3 & 2.08 & 2.56 & & 2.04 & 2.22 \\
4 & 1.12 & 0.34 & & 1.00 & 0.37 \\
5 & 1.51 & 0.96 & 1.76 & 0.54 \\
Mean normal & $1.66 \pm 0.57$ & $1.41 \pm 0.83$ & $1.77 \pm 0.83$ & $1.32 \pm 0.85$ \\
Hartnup disease & 0.10 & 1.58 & 2.50 & 1.83 \\
\hline
\end{tabular}

Table II Maximum rates of increment of serum histidine and $\beta$-alanine after ingestion of carnosine and the constituent free amino acids in five normal subjects and a case of Hartnup disease

\section{Discussion}

Comparisons of the absorption of amino acids after ingestion of carnosine and of the equivalent amounts of free $\beta$-alanine and histidine in this investigation are the opposite of those obtained by Craft et al (1968), comparing the rates of absorption of free glycine and of the peptides glycyl-glycine and glycyl-glycyl-glycine. We have confirmed the latter results using the more exact method of ion-exchange chromatography (Technicon Handbook, 1966). In addition, urinary excretion of free glycine in the 45-minute period after ingestion of glycyl-glycine is approximately twice as high as that after ingestion of the equivalent amount of free glycine, a result to be expected when, after ingestion of the peptide, serum levels of the amino acid are consistently higher during this period.

A superficial and obvious interpretation of the conflicting results would be that there is a fundamental difference between the intestinal absorption of the glycine peptides and that of carnosine. The glycine peptides are presumably taken up intact from the gut lumen and subsequently undergo hydrolysis with delivery of free glycine into the portal capillary blood. The whole process is more rapid than that involved in the corresponding absorption of twice or three times the number of free glycine molecules. By contrast, the present results might apparently favour the view that carnosine is hydrolysed in the fluid within the intestinal lumen and the derived amino acids are subsequently absorbed, a process obviously less rapid than absorption of equivalent amounts of the free amino acids not necessitating prior hydrolysis. A repetition of the two tolerance curves in a case of Hartnup disease to be reported in detail elsewhere (Navab and Asatoor, 1970) has, however, shown that this interpretation is almost certainly incorrect. The current view of the disordered physiology of Hartnup disease is one of defective transport of many mono-amino mono-carboxylic amino acids both in the proximal renal tubular cells and in the jejunal epithelium (Milne, Crawford, Girão, and Loughridge, 1960; Jepson, 1966). Although not absolutely proven for every single involved amino acid, all the amino acids excreted at abnormally high clearance by the kidney are probably poorly absorbed in the jejunum. Clearances of histidine in Hartnup disease are at the level of the glomerular filtration rate, and are in fact higher than those of any other of the involved amino acids (Evered, 1956). By contrast, $\beta$-alanine, a member of a separate amino acid transport group (Scriver, Pueschel, and Davies, 1966; de la Noüe, Newey, and Smyth, 1969), is not excreted in excess in Hartnup disease. Jejunal absorption of $\beta$-alanine is, therefore, likely to be normal, and that of L-histidine to be defective in Hartnup disease. Table II gives the maximum rate of serum amino acid increment, during the absorptive phase in the case of Hartnup disease and in the normal subjects. $\beta$-Alanine absorption is seen to be within normal limits after both carnosine and free amino acid ingestion, whereas histidine absorption in Hartnup disease is normal after carnosine but grossly defective after ingestion of the free amino acid. The result may explain the reason why cases of Hartnup disease preserve an almost normal nutritional status despite gross defects in absorption of many essential amino acids. Thus, tolerance curves fo the essential amino acid phenylalanine were almost completely flat in this case of the disease, and absorption of the free amino acid would be completely inadequate to sustain life. Probably this and other essential amino acids are absorbed mainly as oligopeptides in Hartnup disease, whereas both free amino acid and oligopeptide are absorbed in normal subjects.

A possible explanation of the results of this investigation is that carnosine is absorbed as the entire molecule, but that subsequent intracellular hydrolysis is relatively slow, and is in fact the rate-limiting step in the total absorptive process. By contrast, intracellular hydrolysis of the glycine peptides must be more rapid and does not cause a significant delay in the transport rate. Full confirmation of this interpretation obviously depends on more complete knowledge of the enzyme kinetics of human intestinal peptidases hydrolysing glycine peptides and carnosine. Glycyl-glycine dipeptidase is a very specific enzyme, and is activated by $\mathrm{Co}^{++}$or $\mathrm{Mn}^{++}$(Smith, 1951). Carnosinase hydrolyses glycyl-L-histidine, L-alanyl-, L-histidine, $\beta$-L-aspartylL-histidine, and anserine ( $\beta$-alanyl-I-methyl-histidine) in addition to carnosine, and requires $\mathrm{Zn}^{++}$or $\mathrm{Mn}^{++}$for activity (Hanson and Smith, 1949; Davis, 1956). Similar investigations using these alternative peptides would be both more difficult and more expensive because of lack of availability of the chemicals in pure and bulk supply. The two peptidases are widely distributed in animal tissues, and glycyl-glycine dipeptidase is present in high concentration in intestinal mucosa. Carnosinase has been detected in considerable amount in the intestinal wall of 
the rat (Wood, 1957). Carnosine in the dog is absorbed only after hydrolysis either in the intestinal lumen or in the jejunal cells, but re-synthesis of carnosine occurs in the liver, and carnosine is detectable in the plasma of this species (Elwyn, Parikh, and Shoemaker, 1968). Results obtained in the experimental animal may not necessarily be applicable to man. Probably the main importance of this paper is to draw attention to the uncertainties which face any interpretation of tolerance tests as indices of intestinal absorption in man. If it can be shown, as in the case of glycine peptides, that plasma levels are higher after ingestion of the peptide than after the free amino acid, intestinal absorption of the intact peptide is at least probable. By contrast, the converse result, as in the present investigation, may equally well be interpreted as indicating prior luminal hydrolysis of the peptide, or of absorption of the intact peptide with subsequent slow intracellular hydrolysis. Such results in isolation are, therefore, purely factual and any theoretical interpretation is completely speculative.

\section{References}

Craft, I. L., Geddes, D., Hyde, C. W., Wise, I. J., and Matthews, D. M. (1968). Absorption and malabsorption of glycine and glycine peptides in man. Gut, 9, 425-437.

Davey, C. L. (1957). An ion exchange method of determining carnosine, anserine and their precursors in animal tissue. Nature (Lond.), 179, 209-210.

Davis, N. C. (1956). Action of proteolytic enzymes on some peptides and derivatives containing histidine.J. biol. Chem., 223, 935-947.

De la Noüe, J., Newey, H., and Smyth, D. H. (1969). Transport of alanine isomers by rat small intestine in vitro. J. Physiol. (Lond.), 202, 100-101P.

Elwyn, D. H., Parikh, H. C., and Shoemaker, W. C. (1968). Amino acid movements between gut, liver, and periphery in unanesthetized dogs. Amer. J. Physiol., 215, 1260-1275.

Evered, D. F. (1956). The excretion of amino acids by the human. A quantitative study with ion-exchange chromatography. Biochem. J., 62, 416-427.

Hanson, H. T., and Smith, E. L. (1949). Carnosinase: an enzyme of swine kidney. J. biol. Chem., 179, 789-801.
Jepson, J. B. (1966). Hartnup Disease. In The Metabolic Basis of Inherited Disease, 2nd ed., edited by J. B. Stanbury, J. B. Wyngaarden, and D. S. Fredrickson, pp. 1283-1299. McGraw Hill, New York.

Milne, M. D., Crawford, M. A., Girão, C. B., and Loughridge, L. W. (1960). The metabolic disorder in Hartnup disease. Quart. J. Med., 29, 407-421.

Navab, F., and Asatoor, A. M. (1970). Studies on intestinal absorption of amino acids and a dipeptide in a case of Hartnup disease. Gut (in press).

Newey, H. and Smyth, D. H. (1960). Intracellular hydrolysis of dipeptides during intestinal absorption. J. Physiol. (Lond.), 152, 367-380.

Newey, H., and Smyth, D. H. (1962). Cellular mechanisms in intestinal transfer of amino acids. J. Physiol. (Lond.), $164,527-551$.

Rhodes, J. B., Eichholz, A., and Crane, R. K. (1967). Studies on the organization of the brush border in intestinal epithelial cells. IV. Aminopeptidase activity in microvillus membranes of hamster intestinal brush borders. Biochim. biophys. Acta (Amst.), 135, 959-965.

Scriver, C. R., Pueschel, S., and Davies, E. (1966). Hyper$\beta$-alaninemia associated with $\beta$-aminoaciduria and $\gamma$-aminobutyricaciduria, somnolence and seizures. New Engl.J. Med., 274, 635-643.

Smith, E. L. (1951). The specificity of certa in peptidases. Advanc. Enzymol., 12, 191-257.

Snedecor, G. W. (1946). Statistical Methods, 4th ed. Iowa State College Press, Ames, Iowa.

Technicon Handbook (1966). Techniques in Amino Acid Analysis. pp. 104; 114. Technicon Instruments Co. Ltd., Chertsey, England.

Wiggans, D. S., and Johnston, J. M. (1959). The absorption of peptides. Biochim. biophys. Acta (Amst.), 32, 69-73.

Wiseman, G. (1951). Active stereochemically selective absorption of amino-acids from rat small intestine. J. Physiol. (Lond.), 114, 7-8P.

Wood, T. (1957). Carnosine and carnosinase in rat tissue. Nature (Lond.), 180, 39-40. 